\title{
Satellite tracking highlights the need for international cooperation in marine turtle management
}

\author{
Janice M. Blumenthal ${ }^{1,2, *}$, Joni L. Solomon ${ }^{1}$, Catherine D. Bell ${ }^{2}$, Timothy J. Austin ${ }^{1}$, \\ Gina Ebanks-Petrie ${ }^{1}$, Michael S. Coyne ${ }^{3}$, Annette C. Broderick ${ }^{2}$, Brendan J. Godley ${ }^{2}$ \\ ${ }^{1}$ Department of Environment, PO Box 486, Grand Cayman KY1-1106, Cayman Islands \\ ${ }^{2}$ Marine Turtle Research Group, Centre for Ecology and Conservation, University of Exeter, Cornwall Campus, \\ Penryn TR10 9EZ, UK \\ ${ }^{3}$ Marine Geospatial Ecology Lab, Nicholas School of the Environment and Earth Sciences, Duke University, A321 LSRC, \\ PO Box 90328, Durham, North Carolina 27708, USA
}

\begin{abstract}
We present detailed results of a satellite tracking project following 10 adult female turtles from the Cayman Islands, thought to have once been one of the world's largest rookeries. By tracking the movements of 7 green turtles Chelonia mydas and 3 loggerhead turtles Caretta caretta from now critically reduced rookeries we defined key habitats for internesting movement, migration, and foraging in a range of Caribbean jurisdictions. Turtles tracked from the Cayman Islands traveled to foraging grounds in Belize, Guatemala, Honduras, Mexico, Nicaragua and the USA. This range encompasses a $>2000 \mathrm{~km}$ stretch of Caribbean coastline and the Florida Keys, highlighting the need for international cooperation in identifying and mitigating foraging ground threats. For one of the green turtles, foraging site fidelity was elucidated over the course of two reproductive seasons, and oceanic internesting intervals/post-nesting oceanic circles were defined for the first time in Atlantic loggerhead turtles. In addition to fundamental and applied insights into the biology of the 2 species, this research elucidates geographic scale for potential ecological effects of past decimation of rookeries in the Cayman Islands and highlights the effectiveness of community efforts in support of conservation research.
\end{abstract}

KEY WORDS: Satellite tracking $\cdot$ Spatial ecology $\cdot$ Marine turtle $\cdot$ Chelonia mydas $\cdot$ Caretta caretta Resale or republication not permitted without written consent of the publisher

\section{INTRODUCTION}

Within the Caribbean, centuries of commercial exploitation have resulted in reduction or extirpation of many marine turtle rookeries (Groombridge 1982, Groombridge \& Luxmoore 1989, Jackson 1997, McClenachan et al. 2006). The Cayman Islands epitomize this history of Caribbean marine turtle exploitation. Despite their small size, the islands once supported one of the largest ever green turtle Chelonia mydas rookeries (Groombridge 1982), as well as abundant nesting by loggerhead Caretta caretta and hawksbill Eretmochelys imbricata turtles (Lewis 1940). It is believed that every summer, marine turtles migrated to the isolated islands to nest, leading to reports that vessels, which have lost their latitude in hazy weather, have steered entirely by the noise which these creatures make in swimming to attain the Caymana isles (Long 1774, cited in Lewis 1940 p. 57). By the early 1800s, massive exploitation caused a huge decline in the Cayman Islands green turtle rookery (Lewis 1940), and by the 20th century, rookeries here were considered extinct (Groombridge 1982). However, recent surveys have revealed that nesting by green and loggerhead turtles persists at low levels (Wood \& Wood 1994, Aiken et al. 2001, Bell et al. in press). Additionally, 
nesting by green turtles released from the Cayman Turtle Farm as hatchlings or yearlings has been documented (Bell et al. 2005).

Green turtle rookeries in the Cayman Islands have been reduced from a pre-exploitation estimate of 6.5 million adults (Jackson 1997), to near extirpation (less than 26 nesting females of each species; Bell et al. in press). Conservation of these critically reduced rookeries necessitates delineation of critical habitat and identification of threats. Indeed, research on such rookeries has recently been called for as part of a regional review (McClenachan et al. 2006). However, while nesting beaches in the Cayman Islands are comprehensively monitored (Bell et al. in press), marine turtles spend most of their lives at sea. Over the past few decades, application of flipper tags has been a widely-utilized methodology for studying migration and demographic parameters. However, this method is not ideally suited to monitoring migration for small rookeries, as the likelihood of tag recovery in such situations is extremely small. Additionally, tag recovery locations may be biased toward areas with active marine turtle fisheries, and it may be difficult to determine whether tags were recovered from final destinations or locations en route (Godley et al. 2003, Schroeder et al. 2003).

More recently, molecular genetic methods have demonstrated that many foraging aggregations support turtles from multiple rookeries, and these methods have proven to be of great utility in linking aggregations with their nesting beach origins (loggerhead turtles: e.g. Engstrom et al. 2002, Bass et al. 2004, Roberts et al. 2005, Maffucci et al. 2006, Reece et al. 2006; green turtles: e.g. Lahanas et al. 1998, Bass \& Witzell 2000, Luke et al. 2004). However, with the notable exception of a green turtle foraging ground in Nicaragua (Bass et al. 1998), adult foraging grounds in the Caribbean are largely unsurveyed (Bowen 2003), and if such surveys were undertaken, it is unlikely that contributions from the smallest rookeries would be detected. Therefore, for these rookeries, satellite tracking represents the only viable technique for locating adult foraging grounds.

Migrations of mature marine turtles typically span hundreds or thousands of kilometers (reviewed by Plotkin 2003). Reproductively valuable adults are often harvested and incidentally captured during migration (Witherington 2003, Seminoff 2004 Chelonia mydas. In: IUCN 2006 IUCN Red List of Threatened Species. Available at: www.redlist.org), necessitating documentation of threats on migration routes and foraging grounds (Morreale et al. 1996, Lutcavage et al. 1997, Schroeder et al. 2003, James et al. 2005). Satellite tracking facilitates rapid identification of critical habitat (e.g. Horrocks et al. 2001, James et al. 2005, Troëng et al. 2005), thus representing a valuable tool for elucidating management requirements. In the case of small threatened rookeries the methodology is particularly useful, as with moderate capital investment detailed information can be gathered very quickly.

By tracking wild green and loggerhead turtles, and a green turtle reared in captivity, we set out to rapidly delineate habitats (nesting beaches, internesting areas migratory routes, and foraging grounds) utilized by turtles originating from the Cayman Islands. In this way, we aimed to highlight priorities for conservation.

\section{MATERIALS AND METHODS}

Study area. The Cayman Islands are located south of Cuba in the Caribbean Sea (Fig. 1. Grand Cayman, $19.3^{\circ} \mathrm{N}, 81.4^{\circ} \mathrm{W}$; Little Cayman, $19.7^{\circ} \mathrm{N}, 81.1^{\circ} \mathrm{W}$; Cayman Brac, $19.7^{\circ} \mathrm{N}, 79.9^{\circ} \mathrm{W}$ ). The 3 low-lying oceanic islands are exposed carbonate peaks on the Cayman Ridge with near-vertical slopes dropping to depths in excess of $2000 \mathrm{~m}$ on all sides (Roberts 1994). The islands provide approximately $55 \mathrm{~km}$ of shoreline suitable for marine turtle nesting (Aiken et al. 2001).

Platform Terminal Transmitter deployment. We attached Platform Terminal Transmitters (PTTs) to 7 post-nesting green turtles (G1 to G7) and 3 post-nesting loggerhead turtles (L1 to L3) from June to August 2003 (3 transmitters deployed), 2004 (5 transmitters deployed) and 2005 (3 transmitters deployed). All loggerhead turtles and 6 of the green turtles were tagged in Grand Cayman, while 1 green turtle was tagged in Cayman Brac (Fig. 1). G1 was tracked for 2 reproduc-

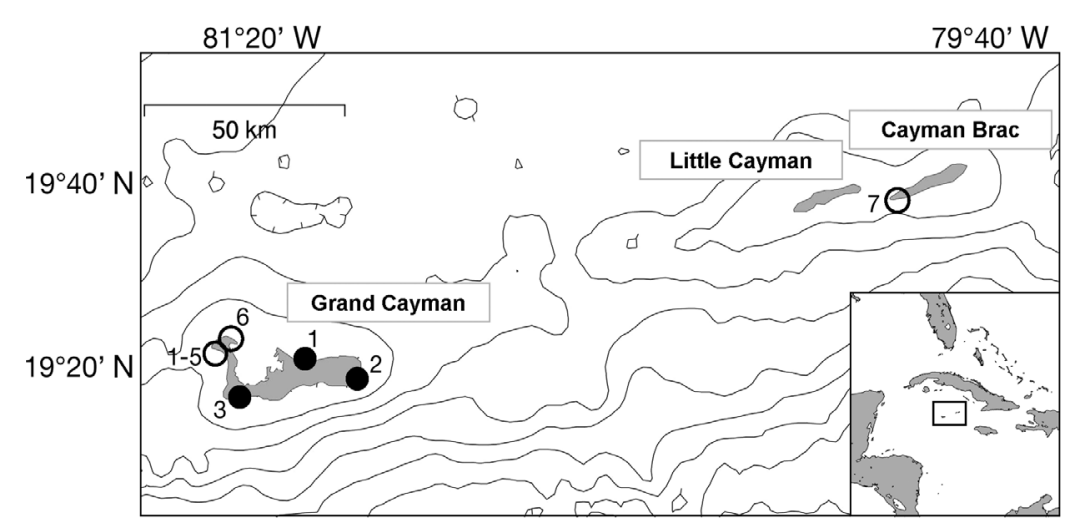

Fig. 1. Cayman Islands, showing location of nesting sites for loggerhead turtles (L1 to 3: filled circles) and green turtles (G1 to G7: open circles). $1000 \mathrm{~m}$ contours are indicated 
tive migrations; originally in 2003 (G1a), and again in 2004 after a 1 yr remigration interval (G1b). The turtle was identified via inconel flipper tags applied the previous year and, as the first PTT had detached, we deployed a new unit in order to track the turtle for a second season. One of the green turtles (G4) had been released from the Cayman Turtle Farm as a yearling in 1988, marked with a 'living tag' (implantation of a $4 \mathrm{~mm}$ disk of lightly colored plastron (lower shell) into the darker carapace, with location of the tag coding for year class) (Bell et al. 2005). At the time of transmitter deployment in 2005, this turtle nested on Seven Mile Beach, Grand Cayman (Cayman Islands Department of Environment unpubl. data).

For a summary of deployment information, biometrics, and satellite transmitter performance for all individuals see Table 1. Sirtrack KiwiSat 101 PTTs were used on all individuals with the exception of 1 Sea Mammal Research Unit (SMRU) Satellite Relay Data Logger tag, which was deployed on L3. To attach the units, a portable wooden corral was erected around each turtle following nesting. The carapace of each turtle was prepared by scrubbing to remove epibionts, sanding lightly, and cleaning with acetone, and a PTT was attached with 2-part epoxy (based on the methods of Godley et al. 2003).

Data filtering. For all transmitters, data were downloaded from the ARGOS satellite system and analyzed via a dedicated program known as the Satellite Tracking and Analysis Tool (STAT: Coyne \& Godley 2005). Location accuracy fell into 6 categories (location class (LC) 3, 2, 1, 0, A, and B). The most accurate positions (LC 3, 2, 1, A; cf. Hays et al. 2001) and biologically realistic speeds $\left(<5 \mathrm{~km} \mathrm{~h}^{-1}\right.$; cf. Luschi et al. 1998) were used to reconstruct routes and calculate distances traveled, although for loggerheads during migration we also included LC B subject to a speed filter in cases where fewer locations were available. Bathymetric data were sampled from the General Bathymetric Chart of the Oceans GEBCO 1-Minute Global Bathymetry Grid (www.bodc.ac.uk/projects/international/ gebco/gebco_digital_atlas).

\section{RESULTS}

\section{Longevity and tracking}

Green turtles were tracked for an extended period from release to last transmission (mean \pm SD $164 \mathrm{~d} \pm$ 71 , range 67 to $281, \mathrm{n}=8$ ). In contrast, loggerhead turtles were tracked for a consistently longer period (mean $\pm \mathrm{SD} 685 \mathrm{~d} \pm 311$, range 379 to $1000, \mathrm{n}=3$ ) . Foraging destination was ascertained for all animals, defined as $>30 \mathrm{~d}$ at a fixed locale $(<200 \mathrm{~km}$ in diameter).

\section{Green turtles}

Movements between satellite transmitter deployment and the beginning of directed migration were documented for green turtles (time in internesting habitat, mean \pm SD $17 \mathrm{~d} \pm 14$, range 0 to $34, \mathrm{n}=8$ ). Prior to commencing migrations to foraging habitat, the majority of green turtles remained in the vicinity of the nesting beach. However, 1 green turtle (G6) circled Grand Cayman (Fig. 2a), and another (G7: the only individual tagged in Cayman Brac) moved to the vicinity of Grand Cayman (maximum distance from nesting

Table 1. Chelonia mydas and Caretta caretta. Summary of biometric, PTT deployment, and migration information for all turtles. Information includes curved carapace length (CCL), PTT deployment date, straight-line distance from nesting beach to foraging ground (displacement), total distance traveled, duration of migration, number of countries passed through during migration, and final foraging destination for all tracked turtles. Turtle G1 was tracked in 2003 (G1a) and 2004 (G1b)

\begin{tabular}{|c|c|c|c|c|c|c|c|c|}
\hline Turtle & $\begin{array}{l}\mathrm{CCL} \\
(\mathrm{cm})\end{array}$ & $\begin{array}{c}\text { PTT } \\
\text { deployment } \\
\text { date }\end{array}$ & $\begin{array}{l}\text { Tag } \\
\text { duration } \\
\text { (d) }\end{array}$ & $\begin{array}{c}\text { Displacement } \\
(\mathrm{km})\end{array}$ & $\begin{array}{c}\text { Distance } \\
\text { traveled } \\
(\mathrm{km})\end{array}$ & $\begin{array}{l}\text { Migration } \\
\text { duration } \\
\text { (d) }\end{array}$ & $\begin{array}{c}\text { Countries } \\
\text { transited } \\
\text { (n) }\end{array}$ & $\begin{array}{c}\text { Foraging } \\
\text { destination }\end{array}$ \\
\hline G1a & 104.0 & 2003-07-27 & 136 & 855 & 874 & 12 & 4 & Guatemala \\
\hline G1b & 105.5 & 2004-08-28 & 67 & 856 & 1023 & 20 & 5 & Guatemala \\
\hline G2 & 107.0 & 2003-08-22 & 281 & 691 & 712 & 11 & 4 & Belize \& Mexico \\
\hline G3 & 109.0 & 2004-08-19 & 144 & 768 & 1265 & 31 & 3 & Mexico \\
\hline G4 & 110.5 & 2005-07-24 & 112 & 745 & 991 & 18 & 3 & Belize \\
\hline G5 & 107.0 & 2005-08-28 & 88 & 632 & 466 & 19 & 3 & Florida Keys \\
\hline G6 & 110.0 & 2005-08-19 & 214 & 623 & 812 & 19 & 3 & Mexico \\
\hline G7 & 110.0 & 2004-08-31 & 269 & 520 & 548 & 11 & 2 & Honduras \\
\hline L1 & 100.0 & 2003-07-28 & 1000 & 791 & 1159 & 49 & 3 & Nicaragua \\
\hline L2 & 105.0 & 2004-07-14 & 675 & 535 & 886 & 39 & 3 & Nicaragua \\
\hline L3 & 100.0 & 2004-06-23 & 379 & 485 & 1020 & 27 & 3 & Nicaragua \\
\hline
\end{tabular}




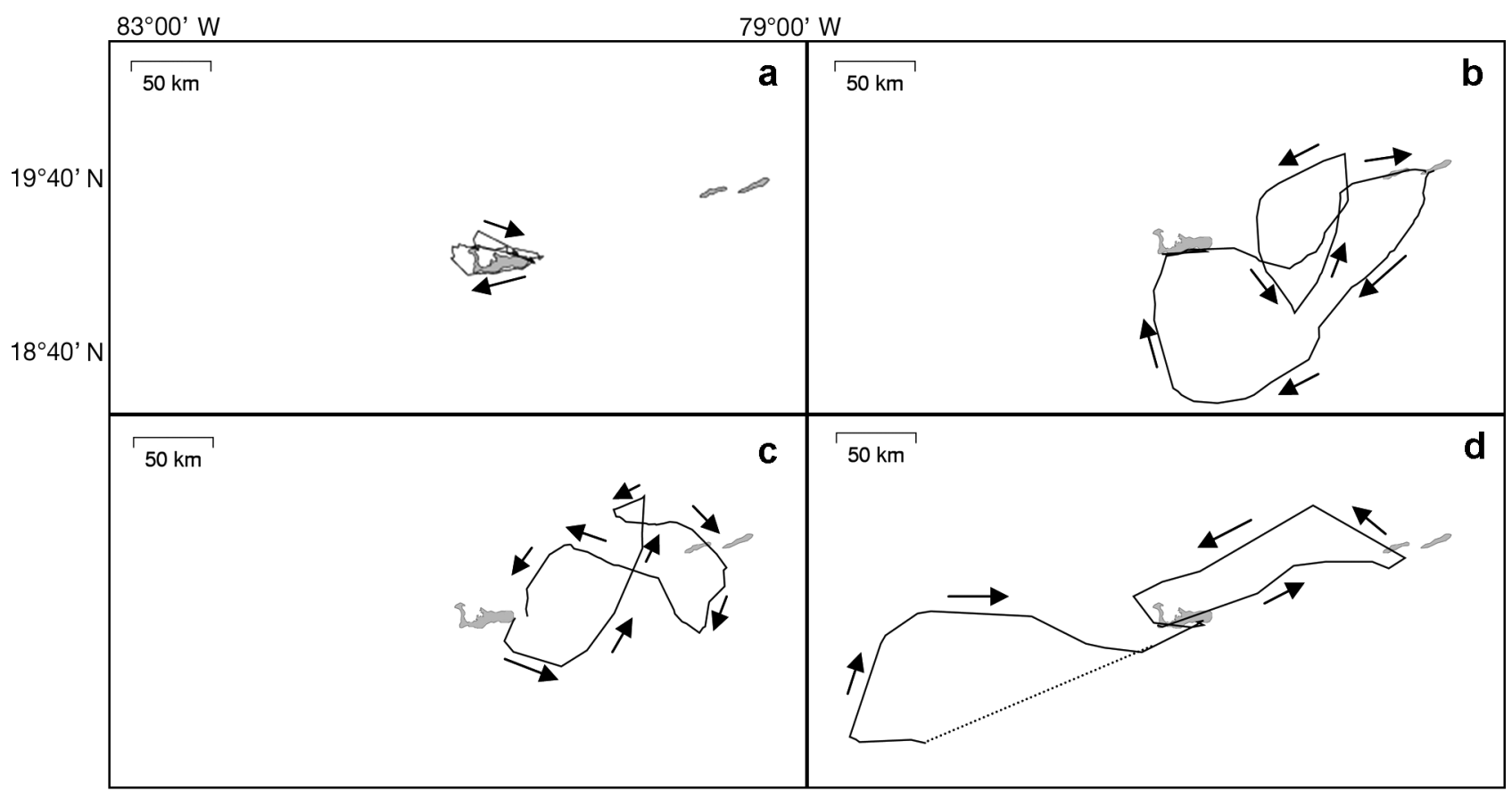

Fig. 2. Chelonia mydas and Caretta caretta. Post-nesting oceanic movements around the Cayman Islands for green and loggerhead turtles (a) G6, (b) G7, (c) L2 and (d) L3. Other tracked turtles remained in the vicinity of the nesting beach prior to beginning directed movements

beach $197 \mathrm{~km}$, mean depth of locations $2940 \mathrm{~m}$ ) before returning to Cayman Brac (Fig. 2b). While re-nesting was not confirmed by beach patrol staff, it is likely that these local movements occurred over the course of internesting intervals. G7 reached Grand Cayman $10 \mathrm{~d}$ after leaving Cayman Brac, and returned to Cayman Brac after an additional $10 \mathrm{~d}$. As this period represents a typical internesting interval for green turtles in the Cayman Islands (Cayman Islands Department of Environment, unpubl. data), G7 may have shifted nesting sites, nesting in Grand Cayman before returning to Cayman Brac. Similarly, G6 returned to the vicinity of the nesting beach on 2 occasions (after 10 and $12 \mathrm{~d}$, respectively), suggesting that movements may also have occurred over the course of 2 internesting intervals.

After beginning directed migration, 6 of the 7 tracked green turtles oriented toward the Central American or Mexican mainland, while 1 individual (G5) oriented northward toward Cuba and the Florida Keys (Fig. 3a). Two movement patterns were observed: direct movement to foraging habitat (Fig. $3 \mathrm{~b}$, Individuals 2 and 7 ) and oceanic crossing followed by coastal migration (Fig. 3c, Individuals 3, 4, 5 and 6). One individual (G1: tracked for 2 reproductive migrations) completed a direct oceanic migration on the first occasion, and an indirect oceanic crossing followed by coastal migration on the second. Duration of migration for green turtles varied from $11 \mathrm{~d}$ (entirely oceanic movement), to $31 \mathrm{~d}$ (9 d oceanic, and $22 \mathrm{~d}$ in coastal waters). Of the 7 green turtles, 6 were tracked to shallow nearshore foraging areas, while the green turtle tracked from Cayman Brac (G7) took up residence in an offshore area (Gorda Bank, Honduras).

\section{Loggerhead turtles}

Movements between satellite transmitter deployment and the beginning of directed migration were documented for all loggerhead turtles (time in internesting habitat, mean \pm SD $22 \mathrm{~d} \pm 15$, range 9 to 38 , $\mathrm{n}=3$ ). L1 remained near shore, while L2 displayed entirely oceanic movements, circling Cayman Brac and Little Cayman before returning to the vicinity of Grand Cayman (Fig. 2c; maximum distance from the nesting beach $135 \mathrm{~km}$, mean depth of locations $2760 \mathrm{~m}$ ). As duration of oceanic movement was $23 \mathrm{~d}$, and nesting does not appear to have occurred in the other islands, this may represent a post-nesting oceanic loop rather than an internesting interval. The third individual (L3) initially circled offshore banks $(10 \mathrm{~d})$, then remained in the vicinity of Grand Cayman (15 d), and finally circled Cayman Brac and Little Cayman $(10 \mathrm{~d})$. While nesting was not confirmed, this 


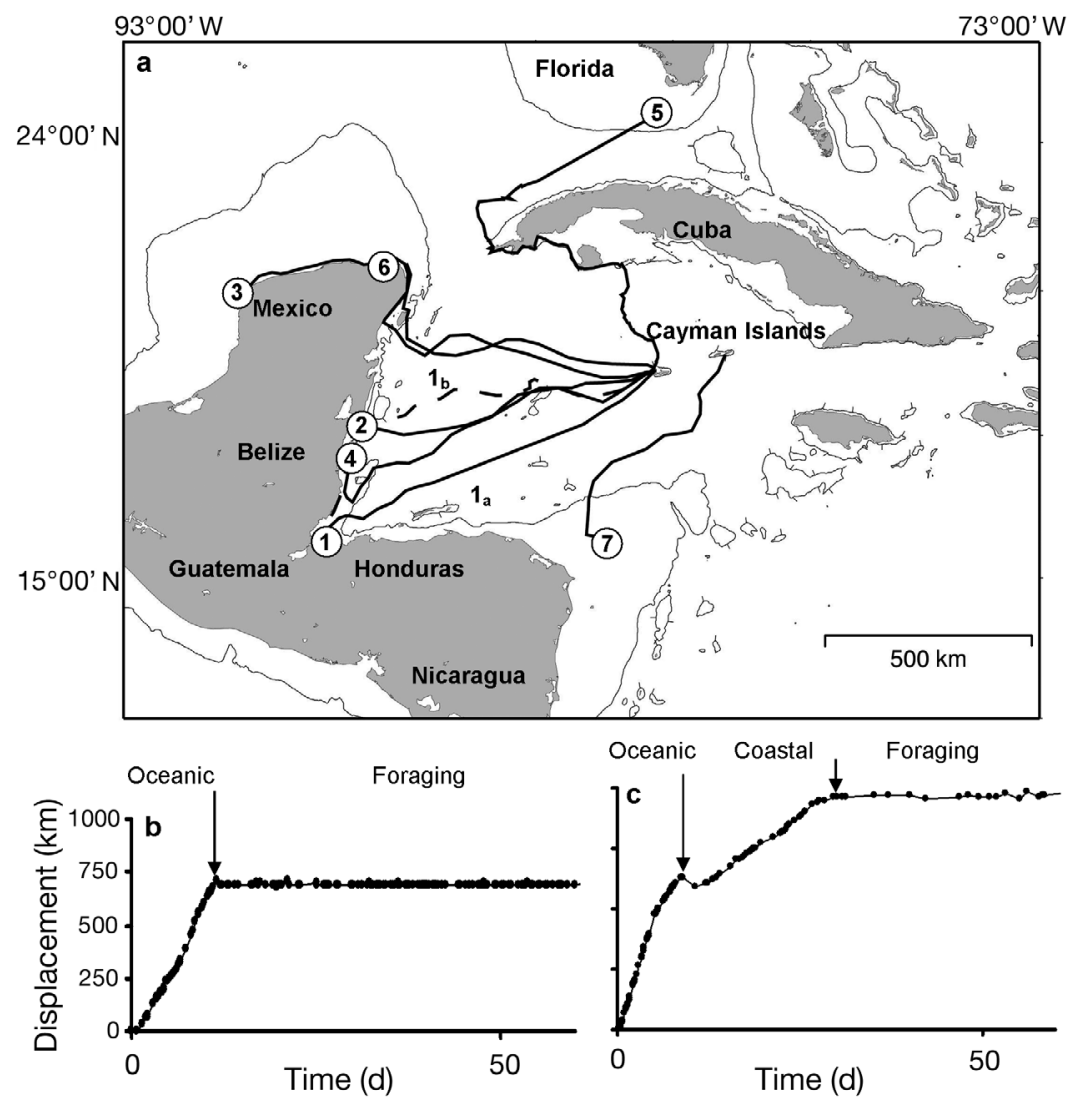

Fig. 3. Chelonia mydas. (a) Green turtle migration routes to foraging grounds in Central America, Mexico, and the USA. G1 was tracked for 2 successive nesting seasons, 2003 (1a, solid line) and 2004 (1b, dashed line). Routes were constructed utilizing positions of location class $3,2,1, \mathrm{~A}$, and speeds less than $5 \mathrm{~km} \mathrm{~h}^{-1}$. The $200 \mathrm{~m}$ contour is indicated. $(\mathrm{b}, \mathrm{c})$ Displacement plots indicating representative (b) oceanic (G2) and (c) coastal (G3) movement patterns. Slope of the line is indicative of speed

The 3 loggerhead turtles utilized Nicaraguan foraging grounds throughout extended tracking, with L2 undertaking a $200 \mathrm{~km}$ habitat shift to the southern Nicaraguan shelf after more than 4 mo at her initial foraging site. After a 1 yr remigration interval, L3 returned to the vicinity of the Cayman Islands and is presumed to have nested. However, as the PTT was functioning intermittently, a detailed return migratory route could not be plotted.

\section{DISCUSSION}

Within $3 \mathrm{yr}$, through deployment of satellite transmitters on 10 turtles, we gained significant insights into the movement of 2 critically reduced rookeries of Caribbean marine turtles. Estimates of rookery size in the Cayman Islands by Bell et al. (in press) suggest that approximately 10 to $20 \%$ of female loggerhead turtles and 30 to $40 \%$ of female green turtles were tagged and tracked to foraging destinations. Satellite tracking results may therefore be representative of previously unknown migratory patterns for the rookeries, providing swift insight into movement across areas under a range of jurisdictions.

\section{Local habitat utilization}

movement pattern, and the seasonality of the movements, suggests oceanic internesting intervals (Fig. 2d; maximum distance from the nesting beach $211 \mathrm{~km}$, mean depth of locations $1900 \mathrm{~m}$ ).

After beginning directed migration, all 3 loggerhead turtles moved through oceanic waters toward the mainland coast of Central America (Fig. 4). Loggerhead turtles utilized an indirect migratory strategy, migrating along the coastal shelf to foraging destinations. Two individuals (L1 and L2) encountered the coastal shelf at the mouth of the Patuca River, Honduras, and subsequently traveled east and south along the shelf (in waters of $<30 \mathrm{~m}$ ). L2 initially took up residence near the Miskito Bank, Nicaragua, and L1 proceeded south to the vicinity of the Corn Islands, Nicaragua. For L3, the complete post-nesting migratory route could not be reconstructed due to a period of few transmissions during migration. However, foraging destination was obtained for this individual on the edge of the Nicaraguan shelf in close proximity to L2.
While some Cayman Islands green and loggerhead turtles remained within a few $\mathrm{km}$ of the nesting beach, others ranged through oceanic waters up to $200 \mathrm{~km}$ away. In prior studies, green and loggerhead turtles generally remained in shallow areas near nesting beaches before beginning migrations (green turtles: Liew \& Chan 1992, Meylan 1995, Hays et al. 2002a; loggerhead turtles: Hays et al. 1991, Godley et al. 2003), though it should be noted that rookeries in the Cayman Islands are in close proximity to oceanic waters. For loggerhead turtles, oceanic habitat utilization during the internesting interval has been documented only in Japan (Sakamoto et al. 1990); however, the highly plastic behavior of this species is gradually being revealed,with an increasing number of studies showing oceanic residence in post-nesting adults (Hatase et al. 2002, Hawkes et al. 2006). 
For green turtles, post-nesting oceanic loops (following the final nesting of the season, yet prior to directed migration) have recently been documented in Tortuguero (Troëng et al. 2005) and Taiwan (Cheng 2000). Looping behavior could be associated with oceanic foraging (Troëng et al. 2005) or attempts to locate a new foraging ground (Luschi et al. 1998). Although turtles from the Cayman Islands briefly encountered shallower waters, it is unlikely that benthic foraging occurred, as mean depth of locations during oceanic movements was greater than $2500 \mathrm{~m}$.

Oceanic movements in turtles from the Cayman Islands may constitute oceanic internesting intervals, shifts in nesting beach utilization, or post-nesting oceanic loops. Historically in the Cayman Islands, exploitation on and near the nesting beach brought an immense rookery to the brink of extinction. During the nesting season, reproductive individuals are typically concentrated in a small area within a single jurisdiction, increasing vulnerability to exploitation (Meylan 1995). For rookeries which underwent heavy exploitation on and near the nesting beach, oceanic movements during the internesting period may have been advantageous. It has been suggested that some turtles nesting in the Cayman Islands may represent recent recruits, following the near extirpation of the historical rookery (Wood \& Wood 1994, Aiken et al. 2001). If this is the case, these colonizing individuals might be expected to possess low nesting site fidelity, which could increase the frequency of behaviors such as oceanic movements during the internesting interval or shifting between island nesting sites.

\section{Migration}

For post-nesting migration, 2 movement patterns were observed: direct movements from the nesting beach to the foraging ground and indirect oceanic crossing followed by extended migration along the coast or coastal shelf. Coastal migrations may serve 2 purposes: (1) facilitating navigation and (2) reducing cost of migration by permitting benthic foraging (Godley et al. 2002, Hays et al. 2002b). Therefore, turtles may minimize the duration of open ocean crossing, even at the expense of increasing total migratory dis- tance (Cheng 2000, Godley et al. 2002, Hays et al. 2002b). Movement patterns do not appear to be fixed for individuals: the green turtle (G1) tracked for 2 consecutive reproductive migrations completed a direct oceanic migration on one occasion and a coastal migration following an indirect ocean crossing on the other. After both reproductive migrations, G1 maintained fidelity to the same foraging site, suggesting orientation toward a distinct and fixed foraging ground rather than selection of suitable habitat from year to year. In a previous study, a green turtle satellite tracked through successive breeding seasons did not return to her initial foraging site during the tracking period (Cheng 2000), although similar fidelity has been suggested in adult female turtles in Australia via flipper tag returns (Limpus et al. 1992, Limpus \& Limpus 2001). In comparison to other turtles, the captive-bred green turtle tracked in this study displayed no apparent anomalous movements. 


\section{Lessons for regional conservation}

Migration routes of turtles from the Cayman Islands exemplify the problems of managing threatened marine turtle rookeries, as turtles from a small area dispersed widely through a wide range of habitats and came under the jurisdiction of many nations. Green turtles traveled to foraging grounds in Belize, Guatemala, Honduras, Mexico, and the USA, with their range encompassing a $>2000 \mathrm{~km}$ stretch of Caribbean coastline and the Florida Keys. This dispersion highlights the importance of broad and collaborative marine turtle management. In contrast, all 3 loggerhead turtles were tracked to foraging habitats in Nicaragua, underscoring the necessity of identifying key habitats and targeting action.

Anthropogenic impacts vary greatly with habitat and jurisdiction: longline fisheries may threaten marine turtles during oceanic movements, while directed take and incidental capture in shrimp trawls and gill nets are critical threats in the neritic zone (Lutcavage et al. 1997). For rookeries in the Cayman Islands, mortality experienced on coastal migratory routes and foraging grounds may represent a greater danger than, for example, longlining, which generally occurs in oceanic waters (Lewison et al. 2004). In the Gulf of Mexico and the Caribbean Sea, shrimp trawls present a significant threat (Groombridge \& Luxmoore 1989, NRC 1990, Henwood et al. 1992). Estimates based on 1987 shrimp landings (Henwood et. al 1992) suggest that at the time over 48000 turtles might have been incidentally captured in Mexican shrimp trawls each year, while over 15000 turtles might have been captured annually in Central America (Henwood et al. 1992) (Table 2). Accuracy of these estimates, species composition of captured turtles, and current magnitude of this threat are unknown, though these data are urgently required to inform regional management.
In addition to experiencing a diversity of threats during the course of reproductive migrations, green and loggerhead turtles from rookeries in the Cayman Islands are subject to many national and international policies and legal instruments. Belize, Guatemala, Honduras, Mexico, Nicaragua, and the USA are signatories to the Convention on International Trade in Endangered Species of Wild Fauna and Flora (CITES, Chacón 2002), which prohibits international trade in marine turtle products but does not regulate domestic trade or habitat protection (Wold 2002). Other international agreements - such as the Convention on the Conservation of Migratory Species of Wild Animals (CMS), the SPAW (Specially Protected Areas and Wildlife) Protocol to the Cartagena Convention, and the Inter-American Convention for the Protection and Conservation of Sea Turtles (IAC) - have the potential to effect international cooperation in marine turtle management, but have not yet been consistently adopted across the Caribbean region (Table 3). Additionally, the nature of national legislation and the effectiveness of its enforcement varies greatly among jurisdictions. Illegal turtle products are commonly marketed in Belize, Guatemala, Honduras, and Mexico (Chacón 2002, Fleming 2001) and in Nicaragua, which appears to be key foraging habitat, it has been estimated that a minimum of 10000 to 11000 green turtles are taken annually, loggerhead turtles are taken incidentally (Lagueux 1998).

As only the Cayman Islands are party to CMS, and other national and international policies and instruments are inconsistently applied, a thorough assessment of the uptake and effectiveness of legislation is needed to prioritize regional action. For green turtles from the Cayman Islands, our results indicate that priorities are in Central America and Mexico, while for loggerhead turtles Honduras and Nicaragua appear to be priority nations.

Table 2. Estimated annual marine turtle captures in jurisdictions utilized by mature green and loggerhead turtles from the Cayman Islands. Nesting: Cayman Islands; Foraging: USA, Mexico, Belize, Guatemala, Honduras, and Nicaragua. Un: number of marine turtle captures not quantified; CC: loggerhead (Caretta caretta); Cm: green (Chelonia mydas); Ei: hawksbill (Eretmochelys imbricata). -: threat does not occur

\begin{tabular}{|c|c|c|c|c|c|c|c|c|}
\hline & \multicolumn{2}{|c|}{ Longlines } & \multicolumn{2}{|c|}{ Shrimp trawls } & \multicolumn{2}{|c|}{ Incidental capture } & \multicolumn{2}{|c|}{ Directed take } \\
\hline & Impact & Species & Impact & Species & Impact & Species & Impact & Species \\
\hline Cayman & - & - & - & - & $<5$ & $\mathrm{CC}_{\mathrm{C}} \mathrm{Cm}$ & $<5$ & $\mathrm{CC}_{\mathrm{C}} \mathrm{Cm}$ \\
\hline Belize & Un & - & $153^{\mathrm{b}}$ & - & Un & - & $500-800^{d}$ & $\mathrm{CC}_{1} \mathrm{Cm}, \mathrm{Ei}$ \\
\hline Guatemala & Un & - & $636^{\mathrm{b}}$ & - & Un & - & Un & - \\
\hline Honduras & Un & - & $2899^{b}$ & - & Un & - & Un & - \\
\hline Mexico & Un & - & $48779^{\mathrm{b}}$ & - & Un & - & Un & - \\
\hline Nicaragua & Un & - & $610^{\mathrm{b}}$ & - & Un & - & $10000-11000^{\mathrm{e}}$ & $\mathrm{Cm}$ \\
\hline USA & $7891^{\mathrm{a}}$ & $C_{C}$ & $5000-50000^{\mathrm{c}}$ & $C_{C}$ & $500-5000^{c}$ & CC & $5-50^{c}$ & $C_{C}$ \\
\hline
\end{tabular}


Table 3. Participation in Multilateral Environmental Agreements (MEAs) in jurisdictions utilized by adult female green and loggerhead turtles from the Cayman Islands. Nesting: Cayman Islands; foraging: USA, Mexico, Belize, Guatemala, Honduras, Nicaragua. MEA abbreviations: CITES: Convention on International Trade in Endangered Species of Wild Fauna and Flora; CMS: Convention on the Conservation of Migratory Species of Wild Animals; Cartagena: Convention for the Protection and Development of the Marine Environment of the Wider Caribbean Region (Cartagena Convention); SPAW: protocol concerning Specially Protected Areas and Wildlife (SPAW Protocol to the Cartagena Convention); IAC: Inter-American Convention for the Protection and Conservation of Sea Turtles; CBD: Convention on Biological Diversity

\begin{tabular}{|c|c|c|c|c|c|c|c|c|c|c|}
\hline & \multirow{2}{*}{$\begin{array}{l}\text { CITES } \\
\text { Party }\end{array}$} & \multirow{2}{*}{$\begin{array}{l}\text { CMS } \\
\text { Party }\end{array}$} & \multicolumn{2}{|c|}{ Cartagena } & \multicolumn{2}{|c|}{ SPAW } & \multicolumn{2}{|c|}{ IAC } & \multicolumn{2}{|c|}{ CBD } \\
\hline & & & Signed & Ratified & Signed & Ratified & Signed & Ratified & Signed & Ratified \\
\hline Cayman Is. & Yes & Yes & Yes & Yes & No & No & No & No & Yes & Yes \\
\hline Belize & Yes & No & - & Yes & No & No & Yes & Yes & Yes & Yes \\
\hline Guatemala & Yes & No & Yes & Yes & Yes & No & Yes & Yes & Yes & Yes \\
\hline Honduras & Yes & No & Yes & No & No & No & Yes & Yes & Yes & Yes \\
\hline Mexico & Yes & No & Yes & Yes & Yes & No & Yes & Yes & Yes & Yes \\
\hline Nicaragua & Yes & No & Yes & No & No & No & Yes & No & Yes & Yes \\
\hline USA & Yes & No & Yes & Yes & Yes & Yes & Yes & Yes & Yes & No \\
\hline
\end{tabular}

\section{Ecological impacts}

Although historical harvesting in the Cayman Islands took place within the confines of a tiny geographic area and a single life-history stage, congregation of reproductive individuals allowed rookeries to be decimated within a few decades (Lewis 1940). As this ecological extinction occurred well before the advent of scientific studies of the marine environment, consequences for seagrass beds and other Caribbean marine habitats are difficult to assess. However, historically, abundant marine turtles undoubtedly played a major role in Caribbean marine ecosystems, acting as grazers and consumers (Bjorndal \& Jackson 2003, Moran \& Bjorndal 2005) and it is therefore presumed that their loss had a drastic impact on the balance of such ecosystems (McClenachan et al. 2006).

Additionally, the near extirpation of nesting turtles in the Cayman Islands may have had demographic consequences for other Caribbean rookeries: a density-dependent effect on foraging grounds (Bjorndal et al. 2000) may have facilitated compensatory population growth in extant Caribbean green turtle rookeries, such as Tortuguero, which has experienced a positive population trend (Troëng \& Rankin 2005). Patterns of dispersion of remnant rookeries must be interpreted with caution, but by tracking surviving members of what may have been one of the largest ever green turtle rookeries (Groombridge 1982) and a significant Caribbean loggerhead rookery (Lewis 1940), we may be able to glimpse historical range and trace impacts of ecological extinction through widespread ecosystems.

In addition to impacting foraging grounds in a range of Caribbean jurisdictions, the extirpation of rookeries from the Cayman Islands is likely to have profoundly impacted local ecosystems. As turtles mediate signifi- cant energy flow from nutrient-rich foraging grounds to nutrient-poor nesting beaches (Bouchard \& Bjorndal 2000), abundant nesting by green and loggerhead turtles is likely to have affected the growth of native beach vegetation and the nutrient content of lagoonal waters off nesting beaches. Therefore, near extinction of these rookeries will have brought about significant shifts in ecosystem dynamics prior to modern surveys of reef environments.

\section{Insights into local conservation: community- sponsored conservation efforts}

While rookeries in the Cayman Islands are now critically small (Bell et al. in press), resident juvenile hawksbill and green turtles are often sighted around all 3 islands. Due to this apparent 'abundance' of turtles, management requirements for rookeries can be difficult to convey (J. M. Blumenthal pers. obs.). Reproductively valuable adult and sub-adult green and loggerhead turtles are targeted in a legal fishery, and illegal take of eggs and nesting females continues in the Cayman Islands (Bell et al. 2006). Satellite tracking has demonstrated the migratory nature of marine turtle rookeries (versus the yearround presence of juveniles), and has facilitated scientific and community discussion of the reproductive value of mature turtles. This concept has great applicability throughout the Caribbean region, as management legislation is often focused on minimum rather than maximum size limits, aimed at protecting juveniles rather than adults (Richardson et al. 2006).

As charismatic species, marine turtles provide an ideal flagship for introducing communities to conservation concepts. Funds for satellite tracking turtles 
from the Cayman Islands were largely raised by school fundraisers and from community sponsors, and migratory paths were made available to the public in near real time on the SEATURTLE.ORG satellite tracking website (www.seaturtle.org/tracking). In the past $3 \mathrm{yr}$, the tracking website as a whole has received more than 3.5 million visits from over 155 countries. With this participatory approach, we aimed to focus awareness on the need for international cooperation in marine turtle management.

Overall, satellite tracking marine turtles from the Cayman Islands across international boundaries provided an accessible introduction to issues of international law surrounding migratory species and offered an unparalleled opportunity to increase awareness among the public and policy makers. This research has enabled us to develop and communicate an understanding of management requirements for threatened marine turtle rookeries, while providing a case study in the difficulties of managing highly-migratory endangered species.

Acknowledgements. Graphics were produced using the Maptool program (a product of SEATURTLE.ORG: www. seaturtle.org/maptool). All tracks were made available to the public in near real time on the SEATURTLE.ORG tracking website: www.seaturtle.org/tracking. We thank Cayman Islands volunteers and sponsors, particularly M. Orr, E. Blanco, G. Oberholtzer, G. Kwong, J. Porter, M. Fowlds, the Olde family, the Richardson family, St. Ignatius High School, Ocean Frontiers Ltd, Jacques Scott Ltd, DiveTech Kids Camp Outreach Program, the Brakka Trakkas, the Ritz-Carlton Grand Cayman's Ambassadors of the Environment program, and Department of Environment research, enforcement, and operations staff. Work in the Cayman Islands was supported by the National Fish and Wildlife Foundation (NFWF), and work in the UK was supported by the Darwin Initiative, European Social Fund, Overseas Territories Environment Programme, Turtles in the UK Overseas Territories (TUKOT) and the National Environment Research Council (NERC). J.B. is supported by a University of Exeter Postgraduate Studentship. The manuscript was improved by the input of 3 anonymous reviewers.

\section{LITERATURE CITED}

Aiken JJ, Godley BJ, Broderick AC, Austin T, Ebanks-Petrie G, Hays GC (2001) Two hundred years after a commercial marine turtle fishery: the current status of marine turtles nesting in the Cayman Islands. Oryx 35:145-151

Bass AL, Witzell WN (2000) Demographic composition of immature green turtles (Chelonia mydas) from the east central Florida coast: evidence from mtDNA markers. Herpetologica 56 (3):357-67

Bass AL, Lagueux CJ, Bowen BW (1998) Origin of green turtles, Chelonia mydas, at 'Sleeping Rocks' off the northeast coast of Nicaragua. Copeia 1998 (4):1064-1069

Bass AL, Epperly SP, Braun-McNeil J (2004) Multi-year analysis of stock composition of a loggerhead turtle
(Caretta caretta) foraging habitat using maximum likelihood and Bayesian methods. Conserv Genet 5:783-796

Bell CDL, Parsons J, Austin TJ, Broderick AC, Ebanks-Petrie G, Godley BJ (2005) Some of them came home: the Cayman Turtle Farm headstarting project for the green turtle Chelonia mydas. Oryx 39:137-148

Bell CD, Blumenthal JM, Austin TJ, Solomon JL, EbanksPetrie G, Broderick AC, Godley BJ (2006) Traditional Caymanian fishery may impede local marine turtle population recovery. Endang Spec Res (in press)

Bell C, Solomon JL, Blumenthal JM, Austin TJ, Ebanks-Petrie G, Broderick AC, Godley BJ (in press) Monitoring and conservation of critically reduced marine turtle nesting populations: lessons from the Cayman Islands. Anim Conserv

Bjorndal KA, Jackson JBC (2003) Roles of sea turtles in marine ecosystems: reconstructing the past. In: Lutz PL, Musick JA, Wyneken J (eds) The biology of sea turtles, Vol II. CRC Press, Boca Raton, FL, p 259-273

Bjorndal KA, Bolten AB, Chaloupka MY (2000) Green turtle somatic growth model: evidence for density dependence. Ecol Appl 10(1):269-282

Bouchard SS, Bjorndal KA (2000) Sea turtles as biological transporters of nutrients and energy from marine to terrestrial ecosystems. Ecology 81:2305-2313

Bowen BW (2003) What is a loggerhead turtle? The genetic perspective. In: Bolten AB, Witherington B (eds) The biology of loggerhead sea turtles. Smithsonian Institution Press, Washington, DC, p 7-27

Chacón D (2002) Diagnóstico sobre el comercio de las tortugas marinas y sus derivados en el istmo Centroamericano. Red regional para la conservación de las tortugas marinas en Centroamérica (RCA). San José

Cheng IJ (2000) Post-nesting migrations of green turtles (Chelonia mydas) at Wan-An Island, Penghu Archipelago, Taiwan. Mar Biol 137:747-754

Coyne MS, Godley BJ (2005) Satellite Tracking and Analysis Tool (STAT): an integrated system for archiving, analyzing and mapping animal tracking data. Mar Ecol Prog Ser 301:1-7

Engstrom TN, Meylan PA, Meylan AB (2002) Origin of juvenile loggerhead turtles (Caretta caretta) in a tropical developmental habitat in Caribbean Panama. Anim Conserv 5:125-133

Fleming EH (2001) Swimming against the tide: recent surveys of exploitation, trade and management of marine turtles in the northern Caribbean. TRAFFIC, Washington, DC

Godley BJ, Richardson S, Broderick AC, Coyne MS, Glen F, Hays GC (2002) Long-term satellite telemetry of the movements and habitat utilisation by green turtles in the Mediterranean. Ecography 25:352-362

Godley BJ, Broderick AC, Glen F, Hays GC (2003) Post-nesting movements and submergence patterns of loggerhead marine turtles in the Mediterranean assessed by satellite tracking. J Exp Mar Biol Ecol 287:119-134

Groombridge B (1982) The IUCN amphibia reptilia red data book, Part I. IUCN, Gland, p 201-207

Groombridge B, Luxmoore R (1989) The green turtle and hawksbill (Reptilia: Cheloniidae): world status, exploitation and trade. CITES Secretariat, Lausanne

Hatase H, Takai N, Matsuzawa Y, Sakamoto W, Omuta K, Goto K, Arai N, Fujiwara T (2002) Size-related differences in feeding habitat use of adult female loggerhead turtles Caretta caretta around Japan determined by stable isotope analyses and satellite telemetry. Mar Ecol Prog Ser 233:273-281 
Hays GC, Webb PI, Hayes JP, Priede IG, French J (1991) Satellite tracking of a loggerhead turtle (Caretta caretta) in the Mediterranean. J Mar Biol Assoc UK 71:743-746

Hays GC, Akesson S, Godley BJ, Luschi P, Santidrian P (2001) The implications of location accuracy for the interpretation of satellite tracking data. Anim Behav 61:1035-1040

Hays GC, Glen F, Broderick AC, Godley BJ, Metcalfe JD (2002a) Behavioural plasticity in a large marine herbivore: contrasting patterns of depth utilisation between two green turtle (Chelonia mydas) populations. Mar Biol 141: 985-990

Hays GC, Broderick AC, Godley BJ, Lovell P, Martin C, McConnel BJ, Richardson S (2002b) Bi-phasal long-distance migration in green turtles. Anim Behav 64:895-898

Hawkes LA, Broderick AC, Coyne MS, Godfrey MS and 5 others (2006) Phenotypically linked dichotomy in sea turtle foraging requires multiple conservation approaches. Curr Biol 16:990-995

Henwood T, Stuntz W, Thompson N (1992) Evaluation of US turtle protective measures under existing TED regulations, including estimates of shrimp trawler related mortality in the wider Caribbean. NOAA Tech Memo NMFSSEFSC-303, Silver Spring, MD

Horrocks JA, Vermeer LA, Krueger B, Coyne M, Schroeder BA, Balazs GH (2001) Migration routes and destination characteristics of post-nesting hawksbill turtles satellitetracked from Barbados, West Indies. Chelonian Conserv Biol 4:107-114

Jackson JBC (1997) Reefs since Columbus. Coral Reefs 16:S23-S32

James MC, Ottensmeyer CA, Myers RA (2005) Identification of high-use habitat and threats to leatherback sea turtles in northern waters: new directions for conservation. Ecol Lett 8:195-201

Lagueux CJ (1998) Marine turtle fishery of Caribbean Nicaragua: human use patterns and harvest trends. PhD dissertation, University of Florida, Gainesville, FL

Lahanas PN, Bjorndal KA, Bolten AB, Encalada SE, Miyamoto MM, Valverde RA, Bowen BW (1998) Genetic composition of a green turtle (Chelonia mydas) feeding ground population: evidence for multiple origins. Mar Biol 130:345-352

Lewis CB (1940) The Cayman Islands and marine turtle. In: Grant C (ed) The herpetology of the Cayman Islands. Bulletin of the Institute of Jamaica Science Series 2, Institute of Jamaica, Kingston, p 56-65

Lewison RL, Freeman SA, Crowder LB (2004) Quantifying the effects of fisheries on threatened species: the impact of pelagic longlines on loggerhead and leatherback sea turtles. Ecol Lett 7:221-231

Liew HC, Chan EH (1993) Biotelemetry of green turtles (Chelonia mydas) in Pulau Redang, Malaysia, during the internesting period. In: Paolo M, Sandro F, Cristina C, Remo B (eds) Biotelemetry XII: Proc 12th Int Symp Biotelemetry, 31 Aug-5 Sep 1992. Ancona. Litograffia Felici, Pisa, p 157-163

Limpus CJ, Limpus DJ (2001) The loggerhead turtle, Caretta caretta, in Queensland: breeding migrations and fidelity to a warm temperate feeding area. Chelonian Conserv Biol 4 (1):142-153

Limpus CJ, Miller JD, Parmenter CJ, Reimer D, McLachlan N, Webb R (1992) Migration of green (Chelonia mydas) and loggerhead (Caretta caretta) turtles to and from Eastern Australian Rookeries. Wildl Res 19:347-358

Long E (1774) History of Jamaica, or general survey of the ancient and modern state of that island. George Metcalf, Frank Cass \& Co, London

Luke K, Horrocks JA, LeRoux RA, Dutton PH (2004) Origins of green turtle (Chelonia mydas) feeding aggregations around Barbados, West Indies. Mar Biol 144:799-805

Luschi P, Hays GC, Del Seppia C, Marsh R, Papi F (1998) The navigational feats of green sea turtles migrating from Ascension Island investigated by satellite telemetry. Proc R Soc Lond Ser B 265:2279-2284

Lutcavage ME, Plotkin P, Witherington B, Lutz PL (1997) Human impacts on sea turtle survival. In: Lutz PL, Musick JA (eds) The biology of sea turtles. CRC Marine Science Series. CRC Press, Boca Raton, FL, p 387-409

Maffucci F, Kooistra WHCF, Bentivegna F (2006) Natal origin of loggerhead turtles, Caretta caretta, in the neritic habitat off the Italian coasts, Central Mediterranean. Biol Conserv 127:183-189

McClenachan L, Jackson JBC, Newman MJH (2006) Conservation implications of historic sea turtle nesting beach loss. Front Ecol Environ 4 (6):290-296

Meylan AB (1995) Behavioral ecology of the west Caribbean green turtle (Chelonia mydas) in the internesting habitat. In: Bjorndal KA (ed) Biology and conservation of sea turtles, revised edn. Smithsonian Institution Press, Washington, DC, p 67-80

Moran KL, Bjorndal KA (2005) Simulated green turtle grazing affects structure and productivity of seagrass pastures. Mar Ecol Prog Ser 305:235-247

Morreale SJ, Standora EA, Spotila JR, Paladino FV (1996) Migration corridor for sea turtles. Nature 384:319-320

NOAA Fisheries (2001) Endangered Species Act section 7 consultation - reinitiation of consultation on the Atlantic highly migratory species fishery management plan and its associated fisheries. National Marine Fisheries Service, Silver Spring, MD

NRC (National Research Council) (1990) Decline of the sea turtles: causes and prevention. National Research Council, Washington, DC

Plotkin P (2003) Adult migrations and habitat use. In: Lutz PL, Musick JA, Wyneken J (eds) The biology of sea turtles, vol II. CCR Press. Boca Raton, FL, p 225-241

Reece JS, Ehrhart LM, Parkinson CL (2006) Mixed stock analysis of juvenile loggerhead turtles in the Indian River Lagoon and implications for marine turtle conservation planning. Conserv Genet 7:345-352

Richardson PB, Broderick AC, Campbell LM, Godley BJ, Ranger S (2006) Marine turtle fisheries in the UK Overseas Territories of the Caribbean: domestic legislation and the requirements of multilateral agreements. J Int Wildl Law Pol 9:223-246

Roberts H (1994) Reefs and lagoons of Grand Cayman. In: Brunt MA, Davies JE (eds) The Cayman Islands: natural history and biogeography, Kluwer Academic Publishers, Dordrecht, p 75-104

Roberts MA, Anderson CJ, Stender B, Segars A, Whittaker JD, Grady JM, Quattro JM (2005) Estimated contribution of Atlantic coastal loggerhead turtle nesting populations to offshore feeding aggregations. Conserv Genet 6:133-139

Sakamoto W, Uchida I, Naito Y, Kureha K, Tujimura M, Sato K (1990) Deep diving behaviour of the Loggerhead turtle near the frontal zone. Nippon Suisan Gakkaishi 56:1435-1443

Schroeder BA, Foley AM, Bagley DA (2003) Nesting patterns, reproductive migrations, and adult foraging areas of loggerhead turtles. In: Bolten AB, Witherington BE (eds) Loggerhead sea turtles. Smithsonian Books, Washington, DC, p 114-124

Smith GW, Eckert KL, Gibson JP (1992) WIDECAST sea turtle recovery action plan for Belize. In: Eckert, KA (ed) CEP 
Technical Report No 18. UNEP Caribbean Environment Programme, Kingston

Troëng S, Rankin E (2005) Long-term conservation efforts contribute to positive green turtle Chelonia mydas nesting trend at Tortuguero, Costa Rica. Biol Conserv 121: 111-116

Troëng S, Evans DR, Harrison E, Lagueux CJ (2005) Migration of green turtles Chelonia mydas from Tortuguero Costa Rica. Mar Biol 148:435-447

Witherington BE (2003) Biological conservation of logger-

Editorial responsibility: Helene Marsh,

Townsville, Queensland, Australia heads: challenges and opportunities. In: Bolten AB, Witherington BE (eds) Loggerhead sea turtles. Smithsonian Books, Washington, DC, p 295-311

Wold C (2002) The status of sea turtles under international environmental law and international environmental agreements. J Int Wildl Law Pol 5:11-48

Wood FE, Wood JR (1994) Sea turtles of the Cayman Islands. In: Brunt MA, Davies JE (eds) The Cayman Islands: natural history and biogeography. Kluwer Academic Publishers, Dordrecht, p 229-236

Submitted: June 14, 2006; Accepted: September 23, 2006 Proofs received from author(s): October 15, 2006 